\title{
Lehmkuhl, Luciene. o Café de Portinari na Exposição do Mundo Português: modernidade e tradição na imagem do Estado Novo brasileiro
}

\author{
Maria de Fátima Fontes Piazza*
}

Uberlândia: Edufu, 2011.268p. il.

The book O Café de Portinari na Exposição do Mundo Português: modernidade e tradição na imagem do Estado Novo brasileiro by the historian Luciene Lehmkuhl, a member of staff at the Federal University of Uberlândia, was originally a doctoral dissertation defended in the Post-Graduate Program in History in the Federal University of Santa Catarina and is methodologically inserted in the ranks of Cultural History, and with rare sensibility enters the so-called 'pictorial turn.'

Café (1935), ${ }^{1}$ an oil painting on canvass by the painter from Brodósqui, is seen as an icon of Brazilian cultural history. It belongs to the collection of the National Museum of Fine Arts, and with this picture Portinari got the second honorable mention of the Carnegie Institute in Pittsburgh in 1935, a distinction obtained by Salvador Dalí and Kokoschka. The picture shows black laborers collecting coffee and loading sacks with it, at the time the principal export of Brazil and a symbol of national strength.

This picture is symbolical of the contradictions inherent in Brazilian society emerging from centuries of slavery, but in it there also emerge representations that will populate Portinari's work in the future, namely its columns, laborers, blacks and mestiços, as well as crop raising - such as coffee growing -, which would integrate the universe of his pictorial production.

Café was the 'dissonant note to the aesthetic harmony' - according to the expression of Prof. Maria Bernardete Ramos Flores who wrote the preface to the book - among the Brazilian works that were part of the Art Stand of the Brazilian Pavilion in the Exhibition of the Portuguese World, held in Lisbon in 1940,

\footnotetext{
* Doctor, PPGH/UFSC. Department of History, Centro de Filosofia e Ciências Humanas, UFSC. Campus Universitário. 88040-900 Florianópolis - SC - Brasil. md.piazza@uol.com.br
} 
which commemorated Portuguese centenaries. The works shown came from the National Museum of Fine Arts and complied with the hierarchy of genres, such as the painting of history, portraits, genders, landscapes and still-life. These works move between realism, impressionism, symbolism and naturalism.

In this pictorial set of 24 oils, Café is not in harmony with the set of characteristics presented from 'academic' or traditional art. Moreover, the Art Stand was not representative of Brazilian artistic production of the 1930s, since its ignored Lasar Segall, Tarsila do Amaral, Anita Malfatti, Di Cavalcanti, Ismael Nery, Cícero Dias and Vicente do Rego Monteiro, amongst others. What it shows is that the modernist aesthetic in such fervor in Brazil was not unanimity in the cultural field or among the estado-novistas elites.

Based on this data the author proposes various questions, including: why was Café part of this exhibition of the Portuguese Estado Novo, a modernist painting in a place dedicated to tradition? Why did the organizing committee of the Art Stand of Brazil select Café amongst so many works representative of the modernist aesthetic? Why did Café deserve so much visibility in this exhibition? Why image did the Estado-novo of Brazil bring to the nationalistic commemorations of its former metropole?

To answer these, the author shrewdly went through archives and libraries in Brazil and Portugal and meticulously investigated the collection of these institutions, without neglecting the cross-referencing of works from the National Museum of Fine Arts which crossed the Atlantic and which were exhibited in the Brazilian Pavilion. This denotes the meticulous work of Luciene Lehmkuhl, as well as the métier of the historian.

The choice of Café to be part of the Art Stand of the Brazilian Pavilion was, amongst other reasons, due to the symbolic capital of the work which had been awarded by the prestigious institution in the US and to the fact that it was considered a symbol of modern Brazilian art by national and international critics. In addition, Portinari was part of an important network of intellectual sociability that even reached into the state bureaucracy, and which allowed official orders of his paintings (for the Ministry of Education and Public Health) and the holding of the Portinari Exhibition in the National Museum of Fine Arts in 1939.

The author calls attention to the magnitude of the Brazilian Pavilion in the Exhibition of the Portuguese World on the banks of the Tagus, which is emblematic of the "coronation of the campaign of formation of LusoBrazilian intimacy." In the wake of nationalist politics, the Portuguese Estado Novo wanted to show to the world Brazil as a 'strong image,' while Portugal 
potentialized its virtual image as the "cradle of discoverers and creators of nations."

While the pictorial scenario presented intended to present the self-image of Brazil to the former Iberian metropole, what stand out are bucolic landscapes, still-lifes, female nudes and Lindoia (an Indian, in a style suited to nineteenth century tastes). This corroborates the perspective that the Art Stand was immersed in the academic tradition of Brazilian art, compatible with the orientation of official institutions, such as the National Museum of Fine Arts, directed by Oswaldo Teixeira, and the Annual Salon.

The visual impact caused by Café among paintings identified as academic meant that Portinari and his work became known in Portugal and were discussed in the Portuguese press. The repercussion involved the cultural field of that country in discussions about central and urgent questions related to modern art in Brazil and Portugal, such as national/international and pure art/ social art, as well as the approximations art/life and art/politics.

The reception of Café in 1940 indelibly marked the paths to be followed by artists and by art critics in Portugal. The historiography of art in Portugal mentions Café as a point of inflection in the history of Portuguese modernism; for some it had an important role in the establishment of neo-realism in that country. The author notes that Portinari was only reclaimed by Portuguese neo-realists in 1946, when he gave an interview to the poet, essayist and painter, Mário Dionísio, after an exhibition in Galerie Charpentier, Paris.

Café is seen as the best example of the Brazilian modernist aesthetic, although in the Exhibition of the Portuguese World it was displayed in the middle of the preponderance of the image of tradition of the Brazilian Estado Novo.

Luciene Lehmkuhl's book is of great importance for the history of Brazilian art, it deserves to be read not just by academics who deal with history and art, images, historiographical practices, documentary and visual collections. It should be read as a 'hunting operation' - in the way proposed by Michel de Certeau - in which will be discovered many methodological subtleties.

\section{NOTES}

${ }^{1}$ Café (1935), oil on canvas, $130 \times 195 \mathrm{~cm}$. Signed and dated in the lower left corner, 'Portinari Brasil 935.' Coleção Museu Nacional de Belas Artes, Rio de Janeiro.

Review received in March 2011. Approved in May 2011. 